\title{
Exchange Rate Exposure, Foreign Currency Derivatives and the Introduction of the Euro: French Evidence
}

\author{
Hoa Nguyen*, Robert Faff** and Andrew Marshall***
}

*School of International Business

Division of Business and Enterprises

University of South Australia

GPO Box 2471

Adelaide SA 5001

Australia
** Department of Accounting and Finance
Faculty of Business and Economics
PO Box 11E
Monash University
Victoria 3800
Australia
*** Department of Accounting and Finance
University of Strathclyde
100 Cathedral Street
Glasgow G4 0LN
Scotland
United Kingdom

* Contacting author. Email: hoa.nguyen@unisa.edu.au Tel: 61883020675 Fax: 61883020512 


\title{
Exchange Rate Exposure, Foreign Currency Derivatives and the Introduction of the Euro: French Evidence
}

\begin{abstract}
In this paper, we investigative the impact of the introduction of the Euro on exchange rate exposures and the subsequent hedging practices of a sample of French corporations. Our findings indicate that the introduction of the Euro led to both a reduction in the number of firms that have significant exchange rate exposure and the absolute size of exposure. In response to these reduced exposures, French firms tend to use foreign currency derivatives less intensively although there has been no change in the number of firms that make use of the instruments. Furthermore, the use of foreign currency derivatives is found to be effective in managing exchange rate exposure but there is insufficient evidence that these instruments are more effective in post Euro periods.
\end{abstract}




\section{Introduction}

Exposure to fluctuations in exchange rates has been identified as one of the major concerns faced by corporations with international activities. Unexpected changes in exchange rates can undermine corporate efforts to preserve the home currency value of their assets and liabilities, which are denominated in foreign currencies. Accordingly, academics have made an attempt to quantify corporate exchange rate exposures and explain how corporations deal with these exposures. Seminal work advanced by Alder and Dumas (1984), Jorion (1990, 1991), Amihud (1993) and Bodnar and Gentry (1993) have ensured a much better understanding of the mechanism of foreign exchange exposures. Despite a few inconsistencies, the existing empirical results suggest that firms generally do not have significant exchange rate exposures, a result that has been argued by many commentators as indicative of exchange rate exposure being 'satisfactorily hedged'. ${ }^{1}$

Given the contemporary empirical framework, in this paper we revisit the exchange rate exposure domain by taking advantage of the historical event of the Euro introduction. The final stage of the introduction program began on January 1, 1999. This not only heralded the birth of a new major currency in the international capital markets but was also expected to bring significant benefits to the participating countries. The European Commission, for example, provides an estimate of 13 billion USD in intraEMU currency conversions prior to the introduction of the Euro and the cost savings

\footnotetext{
${ }^{1}$ See for example Booth (1996) and Bartov, Bodnar and Kaul (1996).
} 
resulting from the reduction in corporate costs of managing intra-Europe foreign exchange risk is estimated to be in the region of $0.33 \%$ to $1.5 \%$ of the aggregate GDP of EMU countries (Wildman 1997 and Hollein 1999).

Using a cross sectional sample of public French corporations for a pre Euro period (1996) and a post Euro period (2000), we aim to initially examine the impact of the introduction of the Euro on firms' exchange rate exposure. More importantly, we also extend previous research by investigating the changing pattern, if any, of corporate use of foreign currency derivatives (FCD) to hedge exchange rate exposure post Euro. Lastly, we provide an empirical comparison of the effectiveness of FCD in alleviating exchange rate exposure and the major determinants of exchange rate exposures in pre and post Euro periods.

Our findings are strongly supportive of the contention that the introduction of the Euro is expected to reduce foreign exchange rate risk for European firms and corporations with strong European linkages. In particular, our results show that, after the introduction of the Euro, there has been a reduction in both the number of French firms that have significant exposures to fluctuation in exchange rates and the absolute exposure coefficients. In response to this reduction in exchange rate exposures, we also find that although the proportion of firms that make use of FCD instruments remains unchanged, the extent to which these instruments are being employed drops significantly from an average of $39.5 \%$ pre Euro to $10 \%$ post Euro. In a second stage regression where we use exchange rate exposures as the dependent variables, we find some evidence that the use of FCD is more effective in alleviating exchange rate exposures after the introduction of the Euro while the impacts of intra-Europe and outside Europe sales on exchange rate 
exposures are largely unclear. Finally, as obvious from the R-squared statistics, our set of independent variables appears to explain a greater proportion of variations in post-Euro exchange rate exposures as opposed to pre-Euro exchange rate exposures of French firms.

The remainder of our paper is structured as follows. In the next section, we offer a brief review of the literature on exchange rate exposure and the use of derivative instruments in managing exchange rate risks. Section 3 describes the sample and econometric framework employed. We discuss the results in Section 4 and Section 5 concludes.

\section{Exchange rate exposure and the use of foreign currency derivatives}

Despite the belief that exchange rate exposure is related to a firm's value in same way via the impact on future cash flows and overseas assets' value, existing empirical work has met with limited success in documenting a significant relationship between firm value an changes in the value of the local currency. Various studies show that only a small proportion of non-financial firms have significant exchange rate exposure (Jorion 1990, 1991, Amihud 1993, Bodnar and Gentry 1993, Bartov and Bodnar 1994, Choi and Prasad 1995). It appears that significant exposure has only been documented primarily for manufacturing and smaller companies (He and $\mathrm{Ng}$ 1998, Chow and Chen 1998).

The lack of a significant correlation between exchange rate risk and stock return has been a subject of much discussion. Bartov and Bodnar (1994), for example, suggest two possible explanations. One is the biased sample selection criteria whereby firms with no exposure are selected into the sample. Second, they reason that investors make 
systematic errors in estimating the change in a firm's value in response to exchange rate fluctuations. They find that abnormal returns are related to lagged changes in the dollar as opposed to instantaneous changes. Shin and Soenen (1999) and Makar and Huffman (2001) also report supportive evidence for this 'lagged response' explanation. However, there is a growing body of research that argues that the observed insignificant exposures (mostly short term) are evidences of firm having successfully managed their exposures. Allayannis and Ofek (2001) report that exchange rate exposure is significantly reduced via the use of foreign currency derivatives. Crabb (2002) also lends support to this conception by concluding that hedging activities partially lead to the failure of previous cross sectional research to identify exchange rate exposure.

Apart from the use of FCD, other factors have also been identified as determinants of exchange rate exposure. Most dominantly, Jorion (1990) show that the degree of foreign involvement is the most important variable in explaining cross sectional variation of exchange rate exposure. Firm size (Chow, Lee and Solt 1997), industry (Shin and Soenen, 1999), liquidity and cash dividends (Chow and Chen, 1997) and industry structure (Marston, 2001) have also been documented as influencing the level of exposure.

Following the introduction of the Euro, a strand of literature has emerged that focuses on the impact of such introduction on the exchange rate exposures of European companies and foreign companies with sales in the euro-zone countries. Christie and Marshall (2001), for example, report that UK multinationals are generally in favour of the Euro due to the reduced costs associated with hedging exchange rate risk. Bartram, Karolyi and Kleimeier (2002) similarly suggest that not only has there been a reduction in 
the volatility of most European trade weighted indices but firms that have a high fraction of sales in the Euro area also experienced a decrease in exchange rate exposures. Their results hold for Euro-zone firms as well as firms in the US, UK and Japan. In the sections to follow, we complement the existing research by providing an assessment of the impact of the Euro on exchange rate exposures of a sample of non-financial French firms. We also contribute to the body of knowledge by examining how such changes in exchange rate exposures have a role to play in risk management practices of these corporations.

\section{Data and Methodology}

\subsection{Data}

Consistent with Bartov and Bodnar (1993) and Geczy, Minton and Schrand (1993), ${ }^{2}$ we selected our sample on the basis that the firms should ex ante be exposed to exchange rate risk. Two conditions are imposed on the sample. First, the firm is required to have at least one subsidiary in a country other than France and second, it is required to have sales outside France in the financial year 1996. Using a search based on these prerequisites from the Global Access - Extel database we obtained an initial sample of 120 firms. The firms are then screened according to the following selection criteria:

- The sample is limited exclusively to parent firms

- Financial statements have to be available for 1996 and 2000. Although this requirement imposes a survivorship bias, we recognize that the benefits for this study in taking an intertemporal approach outweigh this problem. It is further

\footnotetext{
${ }^{2}$ Bartov and Bodnar (1993) argue that one of the reasons that existing research fail to identify significant exchange rate exposures for non-financial firms is a selection bias where firms with no exposure get selected into the sample. Geczy, Minton and Schrand (1997), on the other hand suggest that the decision not to use foreign currency derivatives could be due to the firm having little or no exchange rate exposure.
} 
noted that the sample is biased towards larger firms who make their financial statements more readily available compared to smaller firms that are governed by very limited disclosure rules in France.

- Banks and financial service providers are excluded. This filtering rule is in recognition of the fact that the financial sector is often not an end-user of risk management products. The nature of their business renders them undertaking derivatives positions in the capacity of dealers rather than of users in some circumstances.

This screening process leaves us with a final sample of 99 firms. We then study the financial reports of these firms for a pre-Euro period 1996 and a post-Euro period 2000 to determine the qualitative decision of whether firms use financial derivatives or not and the quantitative decision on the volume of derivative use and the level of the change in the notional amount of derivative use pre and post Euro. Further data relating to the control variables are also obtained from the Financial Statements. Monthly exchange rate and return data are, on the other hand, gathered from Datastream. These data span a period from January 1990 to December 2001.

\subsection{Methodology}

\subsubsection{Measuring exchange rate exposures}

In the spirit of Adler and Dumas (1984) and Jorion (1990), we measure exchange rate exposure for the aggregate sample as the coefficient of the exchange rate variable in a market model. The model is specified as follows: ${ }^{3}$

\footnotetext{
${ }^{3}$ This model is being widely in the literature to quantify exchange rate exposure (see for example Allayannis and Ofek 2001) despite some recent concerns over the reliability with which exchange rate
} 


$$
R_{i t}=\alpha_{0 i}+\alpha_{1 i} R_{X t}+\alpha_{2 i} R_{M t}+\varepsilon_{i}
$$

where $\mathrm{R}_{i t}$ is the monthly continuously compounded stock return of firm $i, \mathrm{R}_{M t}$ is the monthly return on the France CAC 40 market index, $\mathrm{R}_{X t}$ is the monthly fluctuation in the applicable French Trade Weighted Index and $\varepsilon_{\mathrm{i}}$ is the error term.

To enable a comparison between the degrees of exchange rate exposure pre and post Euro, we also measure pre-Euro exposure and post-Euro exposure using the following regression:

$$
R_{i t}=\beta_{0 i}+\beta_{1 i} D_{B i} R_{X t}+\beta_{2 i} D_{A i} R_{X t}+\beta_{3 i} D_{B i} R_{M t}+\beta_{4 i} D_{A i} R_{M t}+\omega_{i}
$$

where $D_{B}$ is a dummy variable set equal to unity if an observation is made prior to the introduction of the EURO in January 1999 and zero otherwise. $\mathrm{D}_{\mathrm{A}}$ is similarly a dummy variable set equal to unity if an observation is made after the introduction of the EURO and zero otherwise. $\omega_{\mathrm{i}}$ is the error term.

\subsubsection{Cross sectional analyses}

First, to investigate the impact of the introduction of the Euro on risk management practices of French firms, we run the following Logistic and Tobit regressions that provide an insight into the factors that are important in the decision to use foreign currency derivatives.

$$
\begin{gathered}
F C D_{i}=\chi_{0}+\chi_{1} \text { Size }_{i}+\chi_{2} M T B V_{i}+\chi_{3} L E V_{i}+\chi_{4} L I Q_{i}+\chi_{5} Q R_{i}+\chi_{6} Y R D U M_{i}+\omega_{i}[3] \\
\text { Extent }_{i}=\delta_{0}+\delta_{1} \text { Size }_{i}+\delta_{2} M T B V_{i}+\delta_{3} L E V_{i}+\delta_{4} L I Q_{i}+\delta_{5} Q R_{i}+\delta_{6} Y_{R D U M_{i}}+\pi_{i}[4]
\end{gathered}
$$

exposures are being measured using this model. Nguyen and Faff (2002), for example, noted that if Interest Rate Parity holds, firm value is more likely to be tied to changes in interest rate rather than exchange rate. For instance, an increase in domestic interest rate not only affects the exchange rate but also the firm's cost of capital, hence firm value. Existing empirical evidence, however, provide very weak support for Interest Rate Parity (see Fama 1984 and Shapiro 1984). 
where FCD is a dummy variable taking the value of 1 if a particular firm uses foreign currency derivatives and zero otherwise and extent is the intensity of derivative usage. The choice of explanatory variables is consistent with hedging theories (see Nance, Smith and Smithson 1993 and Geczy, Minton and Schrand 1997). These explanatory variables include: firm size, market to book value, leverage, liquidity, quick ratio and year dummy. The detailed description of these variables as well as other variables used in this study is provided in Table 1. We pay particular attention to the coefficients on the year dummy variable as these coefficients signify the impact of the introduction of the Euro, if any, on the corporate qualitative decision to adopt FCD and the quantitative decision of how intensive these instruments are to be used.

Second, the changing pattern, if any, of the effectiveness of FCD in alleviating exchange rate exposure pre and post Euro is determined by second stage regressions using the exposure estimated in Equation [2] as the dependant variable. The regressions are specified as follows:

$$
\begin{aligned}
& E X P_{i}=\gamma_{0}+\gamma_{1} F_{C D} * D b+\gamma_{2} F_{i} D_{i} * D a+\gamma_{3} I N E U S A L E S_{i} * D b+\gamma_{4} I N E U S A L E S_{i}^{*} D a \\
& +\gamma_{5} \text { OUTEUSALES }_{i}^{*} \mathrm{Db}+\gamma_{6} \text { OUTEUSALES }_{i}^{*} \mathrm{Da}+\theta_{i} \\
& \operatorname{EXP}_{i}=\lambda_{0}+\lambda_{1} \operatorname{EXTENT}_{i} * D b+\lambda_{2} \text { EXTENT }_{i} * D a+\lambda_{3} \text { INEUSALES }_{i} * D b+\lambda_{4} \text { INEUSALES }_{i} * D a \text { [6] } \\
& +\lambda_{5} \text { OUTEUSALES }_{i} * D b+\lambda_{6} \text { OUTEUSALES }_{i} * D a+u_{i}
\end{aligned}
$$

Equations [5] and [6] recognize that the two most important theoretical determinants of exchange rate exposure are a firm's international involvement (proxied by foreign sales) and its risk management activities (proxied by FCD). In this case, we further partition foreign sales into foreign sales in the Euro region and foreign sales outside the Euro region. This distinction is important as following the introduction of the Euro, it is expected that the ex post level of exposure that French corporations are subject to is only 
a function of foreign sales outside the Euro region. As foreign sales inside the Euro zone are settled in the same currency (the Euro) they should not expose firms to a higher level of exchange rate risk.

Finally, we attempt to provide a cross sectional analysis of exchange rate exposure by running the following regressions:

$$
\begin{gathered}
E X P_{i}=\gamma_{0}+\gamma_{1} F C D_{i} * D b+\gamma_{2} F C D_{i} * D a+\gamma_{n} \sum_{j=1}^{n} \mathrm{X}_{i j} * D a+\gamma_{n+1} \sum_{j=1}^{n} \mathrm{X}_{i j} * D b+\delta_{i} \\
\operatorname{EXP}_{i}=\varphi_{0}+\varphi_{1} \operatorname{Extent}_{i}^{*} D b+\varphi_{2} \text { Extent } t_{i}^{*} D a+\varphi_{n} \sum_{j=1}^{n} \mathrm{X}_{i j} * D a+\varphi_{n+1} \sum_{j=1}^{n} \mathrm{X}_{i j} * D b+\omega_{i}
\end{gathered}
$$

$\mathrm{Xij}$ is a vector of the dependent variables. These variables include: INEUSALES, OUTEURSALES, SIZE, LEV, LIQ, MTBV and QR. The definitions of these variables are detailed in Table 1. Hedging theories predict that larger firms are more likely to have the required financial and human resources to undertake a hedging program and therefore are likely to have smaller exchange rate exposure. Firms with a high degree of leverage, similarly, are more prone to financial distress and thus are more likely to hedge to reduce the volatility of their earnings. Additionally, if a proportion of the firm's borrowing is denominated in a foreign currency, firms tend to make use of FCD to manage the exposure created by their foreign debt holdings. As a result, we predict leverage, if anything, to have a negative relationship with exchange rate exposure. Hedging theories also make provisions for growth opportunities and liquidity as incentive factors for using financial derivatives. Specifically, the more growth options firms have (as proxied by the MTBV ratio), the greater the likelihood that these firms will suffer from 'underinvestment' due to a lack of financial resources. As such, growth firms are more likely to 
make use of derivatives instruments to ensure that their investments are not impacted upon by disruptions in exchange rates. Underinvestment would only eventuate, however, if firms do not have sufficient financial slacks to undertake all their growth options. Higher liquidity (as proxied by LIQ and QR) is therefore predicted to be associated with a lower incidence of hedging and thus higher exchange rate exposures. ${ }^{4}$

\section{Results}

\subsection{Exchange rate exposures of French firms pre and post Euro}

Exchange rate exposures, as estimated using Equations [1] and [2], are reported in Panel A of Table 2. In the first column of Panel A, we present the results relating to exposures for the entire sampling period (Jan 90 to Dec 01). Generally, French firms are overwhelmingly negatively exposed to exchange rate fluctuations. Of all the firms in the sample, approximately $84 \%$ have negative exposures. Additionally, of those who have significant exposures, 97\% have negative exposures. On average, French firms lose $1.44 \%$ in value as the local currency appreciates by $1 \%$ against the Trade Weighted Index. The close proximity between the mean and the median values also suggests that the distribution of exposures is relatively normal. In terms of statistical significance, it is further observed that of all the sample firms, 30.3\% have significant exchange rate exposures. The existing empirical literature has indicated a relatively lower incidence of significant exposures. Jorion (1990), for instance, report that only $5.22 \%$ of his US multinational firms have significant exposures to exchange rate risk. An investigation of industry portfolios in an international setting conducted by Choi and Prasad (1995)

\footnotetext{
${ }^{4}$ Note that the theoretical development of relationships between the explanatory variables and exchange rate exposures is based on hedging theories which assume the use of financial derivatives for hedging purposes, that is to reduce exposures.
} 
reveals that $15 \%, 4 \%$ and $5.9 \%$ of the portfolio are significantly exposed to exchange rate risk in the case of the US, Japan and the UK, respectively. Similarly, $10.34 \%$ has been reported for a cross sectional sample of Australian firms (Nguyen and Faff 2003).

When aggregate exposures are partitioned into pre-Euro and post-Euro exposures, we find that the high percentage of significant exposures is largely related to the pre-Euro period. For the period leading up to the introduction of the Euro $31.91 \%$ of our sample firms have significant exchange rate exposure. After the Euro was introduced, this number reduces to $10.64 \%$ suggesting that, other things being equal, a certain proportion of exchange rate risk has been eliminated through the introduction of the new currency. On average, comparing to the pre-Euro period, both the mean and median post-Euro exposures have halved. Furthermore, while a majority of firms still have negative exposures post Euro, a larger number of firms are found to have positive exposure. This might be due to the changing composition of the Trade Weighted Index which post Euro reflects the importance of EMU's trading partners as opposed to French's trading partners.

Our results lend strong support to exchange rate stabilization efforts, such as the introduction of the Euro. As expected, the new currency eliminates a proportion of exchange rate risk to French firms, leading to a significant reduction in the number of firms that are exposed to significant exchange rate risk post-Euro. To a certain extent, this set of results validates the EMU's expectations of a lower exchange rate risk environment for participating European countries.

Exposures to market risk of our sample firms are further reported in Panel B of Table 1. Consistent with various research on the CAPM, we find that the market risk 
coefficients are mostly positive and in the -2.5 and 2.5 region. Although the mean value of exposure remains quite stable across sampling periods, there is some evidence that fewer firms have significant market risk exposures after the introduction of the Euro. In particular, $26.6 \%$ of all firms have significant market risk exposure pre-Euro while postEuro this figure drops to $15.96 \%$. This result is consistent with Bartram et al who find that the introduction of the Euro is associated with substantial reduction in market risk for their sample firms independent of their geographic locations.

\subsection{Impact of the Euro on Foreign Currency Derivative Usage Practices}

In this section, we examine the question of whether the introduction of the Euro leads to material changes in the pattern of foreign currency derivative usage of French firms. In particular, we provide an investigation of the impact of the Euro on the corporate decision to use FCD and the intensity of FCD usage.

The descriptive statistics of FCD usage by the sample firms, as reported in Panel A of Table 3, indicate that after the introduction of the Euro the number of firms that make use of the instruments remains unchanged. Nevertheless, the intensity with which these instruments are used has declined dramatically. The mean usage, for example, has dropped from $39.55 \%$ to around $10 \%$. The median usage, on the other hand, has decreased from $14.15 \%$ to $3.39 \%$ after the introduction of the Euro. Financial characteristics of sample firms before and after the introduction of the Euro are further presented in Panels B and C. Consistent with existing empirical evidence, we find that in both periods, user of FCD and non-users are statistically distinguishable from each other with respect to firm size and liquidity. FCD users, on average, are found to be larger 
(supporting the notion that hedging exhibit economies of scale) and less liquid (supporting the underinvestment hypothesis). The results relating to domestic sales suggest that in both periods users of FCD have a lower (greater) degree of domestic (foreign) sales. Nevertheless, grouping foreign sales by geographical locations does not provide any additional insights. While users have a higher mean foreign sales within and outside Europe, these differences do not portray any statistical significance. It is interesting to note, however, that there has been an overall growth in foreign sales following the introduction of the Euro. The sector where the growth is most dominant is foreign sales to non-European countries by non derivative users - an increase from $17.55 \%$ of total sales to $30.49 \%$.

The results of a logistic regression that details the cross sectional characteristics that are important in the decision to adopt FCD are reported in Panel A of Table 4. According to the results, the introduction of the Euro has no impact whatsoever on the corporate decision of whether to use FCD or not (insignificant YRDUM variable). This result is consistent with our reported descriptive statistics earlier on that the introduction of the Euro does not change the number of firms who make use of the instruments. The two factors that drive the corporate decision to use FCD, on the other hand, are firm size and leverage. While the result pertaining to firm size is consistent with the literature, the negative relationship between leverage and the likelihood of FCD adoption suggests that firms with less debt in the capital structure are more likely to use FCD. While there is no theoretical argument with regard to the relationship between leverage and the use of FCD (as opposed to the use of interest rate derivatives and aggregate derivative usage), either is it clear why the negative relationship arise. Nguyen and Faff (2003), for example, find 
that leverage is positively related to the likelihood of FCD adoption, a result that they argue is attributable to the issuance of foreign currency denominated debt by Australian corporations.

The quantitative decision of to what degree FCD should be used is examined in Panel B of Table 4. Unlike the 'adoption' case, the introduction of the Euro is found to have a big impact on the intensity of FCD usage. On average, the extent of FCD usage by French firms is expected to be $6 \%$ less that the level pre-Euro. To a certain degree, our findings complement Christie and Marshall's (2001) that the Euro does not alter the main hedging instruments of corporations. Nevertheless, firms appear to have made some adjustments in the way these hedging instruments are used. Together with the Euro, firm size is a strong determinant of the level of FCD usage. It appears that larger firms tend to use FCD more extensively. This result contradicts previous empirical evidence that smaller firms are more likely to use derivatives aggressively to avoid financial distress which are more costly to them. ${ }^{5}$

\subsection{Exchange rate exposure and the use of Foreign Currency Derivatives}

In this section, we explore the use of FCD in reducing exchange rate exposures and whether their effectiveness has been impacted upon by the introduction of the Euro. As noted above, Equations [5] and [6] are developed based on the premise that exchange rate exposure are created via international activities undertaken by the firm and reduced by various hedging technique including the use of FCD. Jorion (1990) for example established that the degree of foreign sales is a major determinant of exchange rate

\footnotetext{
${ }^{5}$ For a theoretical explanation, please refer to Ang, Chua and McConnell (1982), Tufano (1996) and Haushalter (2000)
} 
exposure while Allayannis and Ofek (2001) showed that exchange rate exposure can be reduced by the use of FCD. In order to test the hypothesis that after the introduction of the new currency only foreign sales outside the Euro zone would add to exchange rate exposure of our sample firms, we further partition foreign sales into foreign sales outside Europe and those within Europe. It is expected that foreign sales within the Euro zone would be settled in the same currency, the Euro, and as such should pose no exchange rate risk for the sample firms.

Regression results of Equations [5] and [6] are reported in Table 5. In Panel A, we use the raw exchange rate exposures as estimated in Equation [1] as the dependent variable. The predicted signs of the coefficients are developed on the basis of the observation that our sample firms mostly have negative exposures. Additionally, it is expected that after the introduction of the Euro, foreign sales within Europe will not have any impact on exchange rate exposure for reasons explained above.

As is obvious from Panel A, the degree of foreign involvement and derivative usage appears to have little power in explaining the variation in exposures. An exception, however, exists in the case of FCD usage in pre-Euro period. The use of FCD before the introduction of the Euro seems to have a negative impact on exchange rate exposure, which is consistent with the hypothesis of hedging. Nevertheless, as a majority of our sample firms have negative exposures (as reported in Table 2), a negative impact on exposure implies an increase in the absolute level of exchange rate risk. In contrast to Jorion (1990) and Allayannis and Ofek (2001), we find no evidence that a firm is more exposed to exchange rate fluctuations the more sales it has overseas. In both periods, the coefficients of these foreign sales variables are statistically insignificant. 
Consistent with Nguyen and Faff (2003), to address the issue of 'sign confusion'6 we also use the absolute value of exchange rate exposure as the dependent variable for the second stage regression. The results of these regressions are presented in Panel B. When absolute exposure is used, there is some evidence that the use of FCD in post Euro period is more effective in hedging exchange rate exposure. Nevertheless, the extent to which these instruments are used appears to have no impact on exposure in both pre and post Euro periods. Contrary to our expectations, the amount of foreign sales to countries outside the Euro zone does not seem to have any impact on exposure post Euro while pre Euro there is a thread of evidence suggesting that foreign sales are negatively related to exchange rate exposures. Foreign sales within Europe, on the other hand, influence neither pre Euro nor post Euro exposures.

Motivated by the fact that French firms are overwhelmingly negatively exposed to exchange rate risk, in Panel $\mathrm{C}$ we present the results relating to regressions that look at the sample subset that have negative exposures. The results for negative exposure firms are largely similar to the case of absolute exposures (Panel B). In particular, we find that the use of FCD post Euro can potentially reduce exposure while this effect is absent in pre Euro period. This set of results indicates that the introduction of the Euro does not only impact on the intensity to which firms use FCD but also appear to motivate firms to use these instruments more effectively. Once again, foreign sales have no role to play in explaining exposures.

\footnotetext{
${ }^{6}$ The 'sign confusion' effect refers to the multi dimensional interpretation that can be assigned to the coefficient. For example, a positive FCD coefficient can be interpreted as 'having a positive impact on exchange rate exposure' in the case of a firm with positive exposures. Nevertheless, in the case of a firm with negative exposures, a positive coefficient would mean a reduction in the absolute value of exposure and hence a reduction in exposure. The use of absolute exposure alleviates this problem by investigating only the 'magnitude' of exposure, not the 'direction' of exposure.
} 
To check the robustness of the results reported in Table 5, we rerun Equations [5] and [6] with the addition of control variables that may also have an influence on exposures. These regressions are specified in Equations [7] and [8] and the results are reported in Table 6. Again, to address the 'sign confusion' effect, we present two sets of regression results. In Panel A, the results relating to the cases of positive exposures are presented while Panel B reports the results pertaining to negatively exposed firms. First, it is observed that the addition of control variables improve the explanatory power of the independent variables significantly. Additionally, as indicated by the $R$-squared statistics, it appears that the independent variables can explain a greater degree of variation in exposures in the post-Euro period as opposed to the pre-Euro period.

According to the results in Panel A, the use of FCD among positively exposed firms leads to a statistically significant reduction in exposure in both pre and post Euro periods. Nevertheless, in terms of economic significance, the use of FCD in post-Euro period has much more strength in alleviating exposure. While the results in Table 5 suggest that the reduction in exchange rate exposure is primarily brought about by the incidence of FCD usage, in the presence of the control variables, it appears that the intensity of usage also has a role to play in managing foreign exchange rate risk. However, consistent with the results in Table 5, we find that the degree of foreign sales demonstrate no consistent relationship with exchange rate exposure. The partitioning of foreign sales into intra and inter-Europe sales does not produce any additional meaningful results.

The results in Panel B further confirm our findings that the use of FCD can potentially reduce exchange rate exposures. However, for firms with negative exposures, 
this effect is only evident in the pre Euro period. While it is robust that the use of FCD leads to a reduction in exposure, it is unclear whether such usage is more effective in managing exposure in one currency period compared to another. Contrary to our predictions, post Euro the amount of foreign sales within the Euro region increases exposures while foreign sales outside the Euro zone is associated with a lower absolute value of exposures. Post Euro exposures also appear to be better explained by the control variables. Specifically, after the introduction of the Euro exchange rate exposure is a positive function of the MTBV and the quick ratios and a negative function of leverage and liquidity.

\section{Conclusion}

In this paper we aim to examine the impact of the introduction of the Euro on exchange rate exposures. First of all, we determine if the introduction of the Euro has led to a reduction of exchange rate exposures for a sample of French firms. We extend the analysis by investigating how the change in corporate exchange rate exposure impacts on their derivative usage practices. Finally, we provide empirical evidence relating to the effectiveness of foreign currency derivatives in hedging exchange rate exposure in pre and post Euro periods.

Our findings suggest that the Euro has led to a reduction in both the number of firms that have significant exchange rate exposures and the magnitude of exposure. In response to this declined exposure, firms tend to use foreign currency derivatives less intensively after the introduction of the Euro although the proportion of firms who makes 
use of these instruments remains unchanged. This result is consistent with the argument that the Euro only alleviates, not eliminates, exchange rate exposure.

We also find a thread of evidence that the use of FCD is relatively effective in managing exchange rate risk for this sample of French corporations. Nevertheless, there is not sufficient evidence to conclude that the use of FCD is more effective in post Euro compared to a pre Euro period. In contrast to Jorion (1990) who advance the role of foreign sales as a major determinant of exchange rate exposure, we fail to find any evidence that the degree of foreign sales (both intra and inter-Europe) demonstrates a consistent relationship with exchange rate exposure. Finally, exchange rate exposures of French firms appear to be a function of leverage, liquidity and the MTBV ratio. 


\section{REFERENCE}

Alder, M. and Dumas, B. 1984, 'Exposure to currency risk: Definition and measurement', Financial Management, 13, 41-50.

Allayannis, G. and Ofek, E. 2001, 'Exchange rate exposure, hedging, and the use of foreign currency derivatives', Journal of International Money and Finance, 20, 273-296.

Amihud, Y. 1993, In Exchange rate and corporate performance (Ed, Y. Amihud, R. M. L. E.) Irwin Professional Publishing, New York, pp. 49-59.

Ang, J. S., Chua, J. H. and McConnell, J. J. 1982, 'The administrative costs of corporate bankruptcy: A note', Journal of Finance, 37, 219-226.

Bartov, E. and Bodnar, G. M. 1994, 'Firm valuation, earnings expectations, and the exchange rate exposure effect', Journal of Finance, 49, 1755-1785.

Bartov, E., Bodnar, G.M. and Kaul, A. 1996, 'Exchange rate variability and the riskiness of U.S. multinational firms: Evidence from the breakdown of the Bretton Woods system', Journal of Financial Economics, 42, 105-132.

Bartram, S. M., Karolyi, A. and Kleimeier, S. 2003, 'The impact of the Euro on foreign exchange rate exposures', working paper, Lancaster University.

Bodnar, G. M. and Gentry, W. M. 1993, 'Exchange rate exposure and industry characteristics: Evidence from Canada, Japan and the USA', Journal of International Money and Finance, 12, 29-45.

Booth, L. 1996, 'On the nature of foreign exchange exposure', Journal of Multinational Financial Management, 6, 1-24.

Choi, J. and Prasad, A. 1995, 'Exchange risk sensitivity and its determinants: A firm and industry analysis of US multinationals', Financial Management, 24, 77-88.

Chow, E. H. and Chen, H. L. 1998, 'The determinants of foreign exchange rate exposure', Pacific-Basin Finance Journal, 6, 153-174.

Chow, E. H., Lee, W. Y. and Solt, M. E. 1997, 'The exchange rate risk of asset returns', Journal of Business, 70, 105-123.

Christie, E. and Marshall, A. 2001, 'The impact of the introduction of the Euro on the foreign exchange risk management in UK multinational companies', European Financial Management, 7, 419-432 
Crabb, P. R. 2002, 'Multinational corporations and hedging exchange rate exposure', International Review of Economics and Finance, 11, 299-314.

Geczy, C., Minton, B. A. and Schrand, C. 1997, 'Why firms use foreign currency derivatives', Journal of Finance, 52, 1323-1354.

Haushalter, D. G. 2000, 'Financing policy, basic risk, and corporate hedging: Evidence from Oil and Gas Producers', Journal of Finance, 55, 107-152.

He, J. and $\mathrm{Ng}$, L. 1998, 'The foreign exchange exposure of Japanese multinational corporations', Journal of Finance, 53, 733-753.

Hollein, M. 1999, 'Foreign exchange', World Trade, 12, 43-45

Jorion, P. 1990, 'The exchange rate exposure of US multinationals', Journal of Business, 63, 331-345.

Jorion, P. 1991, 'The pricing of exchange rate risk in the stock market', Journal of Financial and Quantitative Analysis, 26, 363-376.

Makar, S. D. and Huffman, S. P. 2001, 'Foreign exchange derivatives, exchange rate changes, and the value of the firm: US multinationals' use of short term financial instruments to manage currency risk', Journal of Economics and Business, 53, 421-437.

Marston, R. C. 2001, 'The effects of industry structure on economic exposure', Journal of International Money and Finance, 20, 149-164.

Nance, D., Smith, C. W. and Smithson, C. W. 1993, 'On the determinants of corporate hedging', Journal of Finance, 48, 267-284.

Nguyen, H. and Faff, R. 2003, 'Can the use of foreign currency derivatives explain variations in foreign exchange exposure? Evidence from Australian companies', Journal of Multinational Financial Management, 13, 193-215.

Shin, H. H. and Soenen, L. 1999, 'Exposure to currency risk by US multinational corporations', Journal of Multinational Financial Management, 9, 195-107.

Tufano, P. 1996, 'Who manages risk? An empirical examination of risk management practices in the gold mining industry', Journal of Finance, 51, 1097-1137.

Wildman, R. 1997, 'Cash management in anticipation of EMU', The Treasurer, October, 23-27. 


\section{Table 1}

Variable Description

\begin{tabular}{|c|c|}
\hline Variable & Variable Definition (Source) \\
\hline $\begin{array}{l}\text { Exchange Rate Exposure } \\
\text { (EXP) }\end{array}$ & $\begin{array}{l}\text { The exchange rate coefficient estimated from the } \\
\text { following regression } R_{i t}=\alpha_{0 i}+\alpha_{1 i} R_{X t}+\alpha_{2 i} R_{M t}+\varepsilon_{i} \text { [1] }\end{array}$ \\
\hline $\begin{array}{l}\text { Use of Foreign Currency } \\
\text { Derivatives (FCD) }\end{array}$ & $\begin{array}{l}\text { A dummy variable equalling to unity if a firm utilizes } \\
\text { foreign currency derivatives in a financial year and zero } \\
\text { otherwise }\end{array}$ \\
\hline $\begin{array}{l}\text { Extent of Foreign Currency } \\
\text { Derivatives (EXTENT) }\end{array}$ & $\begin{array}{l}\text { Notional amount of foreign currency derivative contracts } \\
\text { scaled by total assets }\end{array}$ \\
\hline Size (SIZE) & Total assets (Individual Financial Statements) \\
\hline Gearing ratio (LEV) & $\begin{array}{l}\text { Ratio of total debt to total equity employed (Individual } \\
\text { Financial Statements) }\end{array}$ \\
\hline Liquidity (LIQ) & $\begin{array}{l}\text { Ratio of cash flow to total assets (Individual Financial } \\
\text { Statements) }\end{array}$ \\
\hline Quick Ratio (QUICK) & $\begin{array}{l}\text { Ratio of current assets less stock divided by current } \\
\text { liabilities (Individual Financial Statements) }\end{array}$ \\
\hline $\begin{array}{l}\text { Market Value /Book Value } \\
\text { (MVBV) }\end{array}$ & $\begin{array}{l}\text { Ratio of market value to book ratio (Global Access - } \\
\text { Primark Extel Card) }\end{array}$ \\
\hline $\begin{array}{l}\text { Foreign sales within Europe } \\
\text { (INEUSALES) }\end{array}$ & $\begin{array}{l}\text { Percentage of sales outside France but within the Europe } \\
\text { zone to total sales (Global Access - Worldscope Global } \\
\text { Company, Individual Financial Statements) }\end{array}$ \\
\hline $\begin{array}{l}\text { Foreign Sales outside Europe } \\
\text { (OUTEUSALES) }\end{array}$ & $\begin{array}{l}\text { Percentage of sales outside Europe to total sales (Global } \\
\text { Access - Worldscope Global Company, Individual } \\
\text { Financial Statements) }\end{array}$ \\
\hline Year Dummy (YRDUM) & $\begin{array}{l}\text { A dummy variable equaling to unity if an observation is } \\
\text { made after the introduction of the EURO (2000) and zero } \\
\text { otherwise }\end{array}$ \\
\hline
\end{tabular}




\section{Table 2 \\ Exchange Rate Exposure of French Firms Pre and Post Euro}

This table reports the firm exposure to exchange rate and market risk. Exchange rate and market exposure of all firms are estimated using the following regression:

$$
R_{i t}=\alpha_{0 i}+\alpha_{1 i} R_{X t}+\alpha_{2 i} R_{M t}+\varepsilon_{i}[1]
$$

Pre-Euro and Post-Euro exchange rate and market exposure are estimated using the following regression:

$$
R_{i t}=\beta_{0 i}+\beta_{1 i} D_{B i} R_{X t}+\beta_{2 i} D_{A i} R_{X t}+\beta_{3 i} D_{B i} R_{M t}+\beta_{4 i} D_{A i} R_{M t}+\omega_{i}[2]
$$

where $\mathrm{R}_{\mathrm{it}}$ is the monthly continuously compounded stock return of firm $i$. $\mathrm{R}_{\mathrm{xt}}$ is the monthly fluctuation in the French Franc Trade Weighted Index, $\mathrm{R}_{\mathrm{mt}}$ is the monthly return on the France CAC 40 market index during the 10-year return horizon. $\mathrm{D}_{\mathrm{B}}$ is a dummy variable set equal to unity if an observation is made prior to the introduction of the EURO in January 1999 and zero otherwise. $\mathrm{D}_{\mathrm{A}}$ is similarly a dummy variable set equal to unity if an observation is made after the introduction of the EURO and zero otherwise. $\varepsilon_{\mathrm{i}}$ and $\omega_{\mathrm{i}}$ are error terms.

\begin{tabular}{|c|c|c|c|}
\hline & All & Pre Euro & Post Euro \\
\hline Mean & -1.4370 & -1.7747 & -0.9885 \\
\hline Median & -1.2758 & -1.2195 & -0.6759 \\
\hline SD & 2.7032 & 3.5900 & 3.5734 \\
\hline Maximum & 9.9183 & 11.9690 & 11.2590 \\
\hline Minimum & -10.4557 & -17.3092 & -11.7735 \\
\hline Positive & 16 & 13 & 38 \\
\hline \# Significant & 1 & 1 & 2 \\
\hline Negative & 83 & 81 & 56 \\
\hline \# Significant & 29 & 29 & 8 \\
\hline$\%$ Significant & 0.3030 & 0.3191 & 0.1064 \\
\hline $\mathrm{n}$ & 99 & 94 & 94 \\
\hline \multicolumn{4}{|c|}{ Panel B: Exposure to Market Risk of French Firms } \\
\hline & All & Pre Euro & Post Euro \\
\hline Mean & 0.3017 & 0.2329 & 0.2603 \\
\hline Median & 0.2262 & 0.2213 & 0.1830 \\
\hline SD & 0.3593 & 0.2554 & 0.4537 \\
\hline Maximum & 2.1422 & 1.4283 & 2.5022 \\
\hline Minimum & -1.1875 & -2.5971 & -0.6013 \\
\hline Positive & 89 & 80 & 73 \\
\hline \# Significant & 34 & 25 & 15 \\
\hline Negative & 10 & 14 & 21 \\
\hline \# Significant & 0 & 0 & 0 \\
\hline$\%$ Significant & 0.3434 & 0.2660 & 0.1596 \\
\hline $\mathrm{n}$ & 99 & 94 & 94 \\
\hline
\end{tabular}

\section{Panel A: Exchange Rate Exposure of French Firms}


Table 3

Descriptive Statistics of Sample Firms in 1996 (Pre-Euro) and 2000 (Post-Euro)

Panel A: Foreign Currency Derivatives Usage Pre and Post Euro

User of FCD

Non-user of FCD

Extent of usage - Mean

\begin{tabular}{cc}
1996 & 2000 \\
\hline 66 & 66 \\
33 & 33 \\
$39.55 \%$ & $10 \%$ \\
$14.15 \%$ & $3.39 \%$
\end{tabular}

Panel B: Financial Characteristics of Sample Firms Pre Euro

\begin{tabular}{|c|c|c|c|c|c|}
\hline & \multicolumn{2}{|c|}{ User $(n=66)$} & \multicolumn{2}{|c|}{ Non-user $(n=33)$} & \multirow[b]{2}{*}{$\mathrm{p}$-value } \\
\hline & Mean & SD & Mean & SD & \\
\hline Firm size ('000) & 5587276 & 8081029 & 754584 & 2218576 & 0.0011 \\
\hline Log(Firm size $)$ & 6.1866 & 0.8560 & 4.9637 & 0.8194 & 0.0000 \\
\hline Gearing ratio & 1.2063 & 2.8266 & 1.7042 & 4.9214 & 0.5247 \\
\hline Liquidity (\%) & 13.3539 & 9.7387 & 23.0016 & 19.7374 & 0.0015 \\
\hline Total sales ('000) & 4865393 & 7058927 & 352448 & 1053151 & 0.0004 \\
\hline Domestic sales & 0.4256 & 0.2408 & 0.5988 & 0.2558 & 0.0015 \\
\hline Foreign Sales within Europe & 0.2817 & 0.1824 & 0.2257 & 0.1736 & 0.1497 \\
\hline Foreign Sales outside Europe & 0.2927 & 0.1953 & 0.1755 & 0.2256 & 0.0445 \\
\hline MTBV & 3.1764 & 3.4307 & 4.0961 & 2.7474 & 0.1523 \\
\hline Quick ratio & 1.0688 & 1.0688 & 1.7564 & 1.7564 & 0.0017 \\
\hline \multicolumn{6}{|c|}{ Panel C: Financial Characteristics of Sample Firms Post Euro } \\
\hline & \multicolumn{2}{|c|}{ User $(n=66)$} & \multicolumn{2}{|c|}{ Non-user $(n=33)$} & \\
\hline & Mean & $\mathrm{SD}$ & Mean & SD & p-value \\
\hline Firm size ('000) & 8093904 & 11693885 & 691123 & 3322183 & 0.0022 \\
\hline Log(Firm size $)$ & 6.3594 & 0.8464 & 5.2027 & 0.6871 & 0.0000 \\
\hline Gearing ratio & 1.0167 & 1.0398 & 0.7552 & 0.8773 & 0.2872 \\
\hline Liquidity $(\%)$ & 11.7582 & 9.0657 & 21.2618 & 18.6204 & 0.0009 \\
\hline Total sales ('000) & 7252214 & 11072608 & 529304 & 3676534 & 0.0041 \\
\hline Domestic sales & 0.3714 & 0.2187 & 0.4397 & 0.2648 & 0.0723 \\
\hline Foreign Sales within Europe & 0.2933 & 0.1670 & 0.2554 & 0.2213 & 0.9870 \\
\hline Foreign Sales outside Europe & 0.3354 & 0.1840 & 0.3049 & 0.3021 & 0.6314 \\
\hline MTBV & 3.7503 & 4.4537 & 7.5024 & 11.2607 & 0.0197 \\
\hline Quick ratio & 0.9765 & 0.4926 & 1.8339 & 1.3074 & 0.0000 \\
\hline
\end{tabular}




\section{Table 4 \\ Impact of the Introduction of the EURO on FCD Usage Practices of French Corporations}

Panel A reports the results of the following logistic regression:

$$
F C D_{i}=\chi_{0}+\chi_{1} S_{i z e}+\chi_{2} M T B V_{i}+\chi_{3} L E V_{i}+\chi_{4} L I Q+\chi_{5} Q R_{i}+\chi_{6} Y R D U M_{i}+\omega_{i}[3]
$$

Panel B reports the results of the following regression:

$$
\text { Extent }_{i}=\delta_{0}+\delta_{1} \text { Size }_{i}+\delta_{2} M T B V_{i}+\delta_{3} L E V_{i}+\delta_{4} L I Q_{i}+\delta_{5} Q R_{i}+\delta_{6} Y R D U M_{i}+\pi_{i}[4]
$$

\begin{tabular}{|c|c|c|c|c|}
\hline \multicolumn{5}{|c|}{ Panel A: The Incidence of Usage } \\
\hline & Predicted Coeff & Coeff & z-stat & p-value \\
\hline $\mathrm{C}$ & & -7.0160 & -4.2521 & 0.0000 \\
\hline LOGTA & + & 1.5241 & 5.5161 & 0.0000 \\
\hline MTBV & + & -0.0099 & -0.3863 & 0.6993 \\
\hline LEV & $?$ & -0.1098 & -1.8563 & 0.0634 \\
\hline LIQ & - & -0.0119 & -0.5668 & 0.5708 \\
\hline QR & - & -0.2875 & -1.0020 & 0.3163 \\
\hline YRDUM & - & -0.5683 & -0.9807 & 0.3267 \\
\hline$R$-Squared & 0.3077 & & & \\
\hline \multicolumn{5}{|c|}{ Panel B: The Intensity of Usage } \\
\hline & Predicted Coeff & Coeff & t-stat & $\mathrm{p}$-value \\
\hline $\mathrm{C}$ & & -7.0423 & -1.0653 & 0.2884 \\
\hline LOGTA & - & 3.3214 & 3.5843 & 0.0004 \\
\hline MTBV & + & -0.1184 & -1.2594 & 0.2097 \\
\hline LEV & $?$ & 0.0740 & 0.1793 & 0.8579 \\
\hline LIQ & - & -0.0926 & -0.8263 & 0.4099 \\
\hline QR & - & -0.0400 & -0.0641 & 0.9489 \\
\hline YRDUM & - & -6.0575 & -1.8880 & 0.0608 \\
\hline$R$-Squared & 0.0895 & & & \\
\hline
\end{tabular}

The definitions of the variables are provided in Table 1. $\omega_{\mathrm{i}}$ and $\pi_{\mathrm{i}}$ are error terms. 
Table 5

The Use of Foreign Currency Derivatives in Reducing Exchange Rate Exposure

This table presents the results of the following equations:

$$
\begin{aligned}
& E X P_{i}=\gamma_{0}+\gamma_{1} F C D_{i} * D b+\gamma_{2} F C D_{i} * D a+\gamma_{3} I N E U S A L E S_{i}^{*} D b+\gamma_{4} \text { INEUSALES }_{i}^{*} \text { Da [5] } \\
& +\gamma_{5} \text { OUTEUSALES }{ }_{i}^{*} \mathrm{Db}+\gamma_{6} \text { OUTEUSALES } * D a+\theta_{i} \\
& E X P_{i}=\lambda_{0}+\lambda_{1} E_{X X E N T_{i}} * D b+\lambda_{2} E_{X T E N T} * D a+\lambda_{3} I N E U S A L E S_{i}^{*} D b+\lambda_{4} \text { INEUSALES }_{i}^{*} \text { Da [6] } \\
& +\lambda_{5} \text { OUTEUSALES } * \text { Db }+\lambda_{6} \text { OUTEUSALES } * D a+u_{i}
\end{aligned}
$$

Panel A reports results with the dependant variable being the raw exposure as estimated in Equation [1]. Panel B reports results with the dependant variable being the absolute value of the exposure estimated in Equation [1]. Panel $\mathrm{C}$ reports results with dependant variable being negative exchange rate exposure estimated in Equation [1]. Db is a dummy variable equaling to unity if the observation is made in financial year 1996 and zero otherwise. Da is a dummy variable equaling to unity if the

\begin{tabular}{|c|c|c|c|c|c|}
\hline & & \multicolumn{2}{|c|}{ Pre-Euro } & \multicolumn{2}{|c|}{ Post-Euro } \\
\hline & Predicted Sign & Usage & Extent & Usage & Extent \\
\hline Constant & $?$ & $\begin{array}{c}-0.9540 \\
(-1.0023)\end{array}$ & $\begin{array}{c}-1.6430 \\
(-1.5535)\end{array}$ & $\begin{array}{c}-0.9540 \\
(-1.0023)\end{array}$ & $\begin{array}{c}-1.6430 \\
(-1.5535)\end{array}$ \\
\hline FCD use & + & $\begin{array}{l}-2.7848^{a} \\
(-2.9451)\end{array}$ & $\begin{array}{c}0.0000 \\
(0.0971)\end{array}$ & $\begin{array}{c}0.3561 \\
(0.4352)\end{array}$ & $\begin{array}{c}-0.0463 \\
(-1.2182)\end{array}$ \\
\hline FS outside Europe & - & $\begin{array}{c}2.1932 \\
(1.1524)\end{array}$ & $\begin{array}{c}-0.9558 \\
(-0.4959)\end{array}$ & $\begin{array}{c}-3.4837 \\
(-1.3097)\end{array}$ & $\begin{array}{c}-1.4331 \\
(-0.5455)\end{array}$ \\
\hline FS within Europe & - & $\begin{array}{c}2.3969 \\
(1.2719)\end{array}$ & $\begin{array}{c}1.2101 \\
(0.5349)\end{array}$ & $\begin{array}{c}0.9383 \\
(0.4856)\end{array}$ & $\begin{array}{c}2.1007 \\
(0.8972)\end{array}$ \\
\hline$R$-squared & & 0.1004 & 0.0466 & 0.1004 & 0.0466 \\
\hline \multicolumn{6}{|c|}{ Panel B: Absolute Exchange Rate Exposure and the Use of FCD } \\
\hline & & \multicolumn{2}{|c|}{ Pre-Euro } & \multicolumn{2}{|c|}{ Post-Euro } \\
\hline & Predicted Sign & Usage & Extent & Usage & Extent \\
\hline Constant & $?$ & $\begin{array}{c}3.1712^{\mathrm{a}} \\
(4.0279)\end{array}$ & $\begin{array}{c}3.1897^{\mathrm{a}} \\
(3.5831)\end{array}$ & $\begin{array}{c}3.1712^{\mathrm{a}} \\
(4.0279)\end{array}$ & $\begin{array}{c}3.1897^{\mathrm{a}} \\
(3.5831)\end{array}$ \\
\hline FCD use & - & $\begin{array}{c}0.3994 \\
(0.4857)\end{array}$ & $\begin{array}{c}-0.0005 \\
(-1.4867)\end{array}$ & $\begin{array}{l}-1.0634^{c} \\
(-1.7089)\end{array}$ & $\begin{array}{c}0.0217 \\
(0.6300)\end{array}$ \\
\hline FS outside Europe & + & $\begin{array}{l}-3.4674^{c} \\
(-1.9088)\end{array}$ & $\begin{array}{l}-2.7599^{c} \\
(-1.7969)\end{array}$ & $\begin{array}{c}1.9439 \\
(0.8447)\end{array}$ & $\begin{array}{c}0.8462 \\
(0.3677)\end{array}$ \\
\hline FS within Europe & + & $\begin{array}{l}-0.4499 \\
(0.2730)\end{array}$ & $\begin{array}{c}0.0831 \\
(0.0453)\end{array}$ & $\begin{array}{c}-1.2589 \\
(-0.8120)\end{array}$ & $\begin{array}{c}-3.0360 \\
(-1.5078)\end{array}$ \\
\hline$R$-squared & & 0.0598 & 0.0466 & 0.0598 & 0.0466 \\
\hline
\end{tabular}
observation is made in financial year 2000 and zero otherwise. Definitions of other variables are presented in Table 1. $\theta_{\mathrm{i}}$ and $\mathrm{u}_{\mathrm{i}}$ are error terms. t-statistics are in brackets.

Panel A: Raw Exchange Rate Exposure and the Use of FCD 


\section{Panel C: Negative Exchange Rate Exposure and the Use of FCD}

\begin{tabular}{lccccc}
\hline & & \multicolumn{2}{c}{ Pre-Euro } & \multicolumn{2}{c}{ Post-Euro } \\
& Predicted Sign & Usage & Extent & Usage & Extent \\
\cline { 2 - 6 } Constant & $?$ & $-3.1830^{\mathrm{a}}$ & $-3.4052^{\mathrm{a}}$ & $-3.1830^{\mathrm{a}}$ & $-3.4052^{\mathrm{a}}$ \\
& & $(3.3282)$ & $(-3.0066)$ & $(-3.3282)$ & $(-3.0066)$ \\
FCD use & + & -0.8026 & 0.0006 & $1.8606^{\mathrm{c}}$ & -0.0231 \\
& & $(-0.9408)$ & $(1.4802)$ & $(2.0103)$ & $(-0.5660)$ \\
FS outside Europe & - & 3.3395 & 2.5039 & -3.4781 & -1.6298 \\
& & $(1.6579)$ & $(1.3270)$ & $(-1.3988)$ & $(-0.6013)$ \\
FS within Europe & - & 1.7634 & 0.9472 & -0.7313 & 2.9362 \\
& & $(0.9338)$ & $(0.4384)$ & $(-0.3156)$ & $(1.0366)$ \\
$R$-squared & & 0.0909 & 0.0601 & 0.0909 & 0.0601 \\
\hline
\end{tabular}

${ }^{\text {a }}$ Significant at the $1 \%$ level

${ }^{\mathrm{b}}$ Significant at the $5 \%$ level

${ }^{\mathrm{c}}$ Significant at the $10 \%$ level 
Table 6

Cross Sectional Analysis of Exchange Rate Exposure

This table reports the results of the following regressions:

$$
\begin{gathered}
E X P_{i}=\gamma_{0}+\gamma_{1} F C D_{i}^{*} D b+\gamma_{2} F C D_{i}^{*} D a+\gamma_{n} \sum_{j=1}^{n} \mathrm{X}_{i j} * D a+\gamma_{n+1} \sum_{j=1}^{n} \mathrm{X}_{i j} * D b+\delta_{i} \\
\operatorname{EXP}_{i}=\varphi_{0}+\varphi_{1} \operatorname{Extent}_{i}^{*} D b+\varphi_{2} \operatorname{Extent}_{i}^{*} D a+\varphi_{n} \sum_{j=1}^{n} \mathrm{X}_{i j} * D a+\varphi_{n+1} \sum_{j=1}^{n} \mathrm{X}_{i j} * D b+\omega_{i}
\end{gathered}
$$

where FCD is a dummy variable taking the value of unity when a firm uses Foreign Currency Derivatives and zero otherwise. Extent is the total notional amount of foreign currency derivatives contracts scaled by total assets. Xij is a vector of the dependent variables. These variables include: INEUSALES, OUTEURSALES, SIZE, LEV, LIQ, MTBV and QR. The definitions of these variables are provided in Table 1 . Db is a dummy variable equaling to unity if the observation is made in financial year 1996 and zero otherwise. Da is a dummy variable equaling to unity if the observation is made in financial year 2000 and zero otherwise. $\delta_{\mathrm{i}}$ and $\omega_{\mathrm{i}}$ are error terms.

Panel A reports the results of Equations [7] and [8] for a subset of firms that have positive exchange rate exposure while Panel B reports the results of Equations [7] and [8] for the subset of firms that

\begin{tabular}{|c|c|c|c|c|c|}
\hline \multicolumn{6}{|c|}{ Panel A: Positive Exchange Rate Exposure } \\
\hline \multirow[b]{2}{*}{ Constant } & \multirow[t]{2}{*}{ Pred. Sign } & \multicolumn{2}{|c|}{ Pre-Euro } & \multicolumn{2}{|c|}{ Post-Euro } \\
\hline & & $\begin{array}{c}4.1719 \\
(1.6702)\end{array}$ & $\begin{array}{c}4.7886 \\
(1.7023)\end{array}$ & $\begin{array}{c}5.2550^{\mathrm{c}} \\
(1.9227)\end{array}$ & $\begin{array}{c}3.3384 \\
(1.2798)\end{array}$ \\
\hline Use of FCD & - & $\begin{array}{c}-0.7817 \\
(-1.0222)\end{array}$ & & $\begin{array}{c}0.7186 \\
(1.0471)\end{array}$ & \\
\hline Extent of FCD & - & & $\begin{array}{c}-0.0015^{b} \\
(-2.5858)\end{array}$ & & $\begin{array}{c}-0.0323^{b} \\
(-2.5712)\end{array}$ \\
\hline Foreign Sales Within Europe & $+/ ?$ & $\begin{array}{c}0.5594 \\
(0.2055)\end{array}$ & $\begin{array}{c}0.3752 \\
(0.1347)\end{array}$ & $\begin{array}{c}-0.5399 \\
(-0.2402)\end{array}$ & $\begin{array}{c}1.6011 \\
(0.8728)\end{array}$ \\
\hline Foreign Sales Outside Europe & + & $\begin{array}{c}-1.7865 \\
(-1.4284)\end{array}$ & $\begin{array}{l}-2.4380^{c} \\
(-1.8352)\end{array}$ & $\begin{array}{c}0.7058 \\
(0.6474)\end{array}$ & $\begin{array}{c}-0.4619 \\
(-0.8132)\end{array}$ \\
\hline Size & - & $\begin{array}{c}-0.3641 \\
(-0.9698)\end{array}$ & $\begin{array}{c}-0.5378 \\
(-1.2719)\end{array}$ & $\begin{array}{c}-0.3917 \\
(-0.9615)\end{array}$ & $\begin{array}{c}-0.2174 \\
(-0.5735)\end{array}$ \\
\hline Leverage & $?$ & $\begin{array}{c}0.0089 \\
(0.0315)\end{array}$ & $\begin{array}{c}0.1099 \\
(0.3923)\end{array}$ & $\begin{array}{c}-0.3391 \\
(-1.5554)\end{array}$ & $\begin{array}{c}-0.1170 \\
(-0.6849)\end{array}$ \\
\hline Liquidity & + & $\begin{array}{c}-0.0374 \\
(-1.0798)\end{array}$ & $\begin{array}{c}-0.0396 \\
(-1.0987)\end{array}$ & $\begin{array}{c}-0.0085 \\
(-0.3341)\end{array}$ & $\begin{array}{c}-1.5540 \\
(-0.5095)\end{array}$ \\
\hline MTBV & - & $\begin{array}{c}0.0456 \\
(0.2716)\end{array}$ & $\begin{array}{c}0.0980 \\
(0.4870)\end{array}$ & $\begin{array}{c}-0.0579 \\
(-0.7551)\end{array}$ & $\begin{array}{c}0.0163 \\
(0.2484)\end{array}$ \\
\hline Quick Ratio & + & $\begin{array}{c}0.9084 \\
(1.2710)\end{array}$ & $\begin{array}{c}0.9729 \\
(1.2225)\end{array}$ & $\begin{array}{l}-1.2325^{\mathrm{c}} \\
(-1.9517)\end{array}$ & $\begin{array}{c}-0.6808 \\
(-1.2722)\end{array}$ \\
\hline$R$-Squared & & 0.2371 & 0.2801 & 0.3742 & 0.4118 \\
\hline
\end{tabular}
have negative exchange rate exposure. $t$-statistics are in brackets. 


\begin{tabular}{|c|c|c|c|c|c|}
\hline \multicolumn{6}{|c|}{ Panel B: Negative Exchange Rate Exposure } \\
\hline \multirow[b]{2}{*}{ Constant } & \multirow[t]{2}{*}{ Pred Sign } & \multicolumn{2}{|c|}{ Pre-Euro } & \multicolumn{2}{|c|}{ Post-Euro } \\
\hline & & $\begin{array}{l}-6.1327^{\mathrm{c}} \\
(-1.8863)\end{array}$ & $\begin{array}{l}-5.8069^{c} \\
(-1.7295)\end{array}$ & $\begin{array}{c}-4.3057 \\
(-1.4163)\end{array}$ & $\begin{array}{c}-4.2626 \\
(-1.4558)\end{array}$ \\
\hline Use of FCD & + & $\begin{array}{c}0.9123 \\
(0.6098)\end{array}$ & & $\begin{array}{c}-1.7392 \\
(-1.4066)\end{array}$ & \\
\hline Extent of FCD & + & & $\begin{array}{c}0.0019^{\mathrm{a}} \\
(2.9193)\end{array}$ & & $\begin{array}{c}-0.0220 \\
(-0.6987)\end{array}$ \\
\hline Foreign Sales Within Europe & $-/ ?$ & $\begin{array}{c}-1.2355 \\
(-0.4932)\end{array}$ & $\begin{array}{l}3.2674^{\mathrm{b}} \\
(2.1878)\end{array}$ & $\begin{array}{l}-4.1208^{a} \\
(-2.8554)\end{array}$ & $\begin{array}{l}-4.1130^{b} \\
(-2.6064)\end{array}$ \\
\hline Foreign Sales Outside Europe & - & $\begin{array}{c}1.0326 \\
(0.4727)\end{array}$ & $\begin{array}{c}-0.2590 \\
(-0.1411)\end{array}$ & $\begin{array}{c}3.2790^{\mathrm{b}} \\
(2.0568)\end{array}$ & $\begin{array}{c}1.8316 \\
(1.0575)\end{array}$ \\
\hline Size & + & $\begin{array}{c}0.4085 \\
(0.5856)\end{array}$ & $\begin{array}{c}0.1825 \\
(0.3559)\end{array}$ & $\begin{array}{c}0.8441 \\
(1.4991)\end{array}$ & $\begin{array}{c}0.5960 \\
(1.4200)\end{array}$ \\
\hline Leverage & $?$ & $\begin{array}{c}0.4844 \\
(1.1156)\end{array}$ & $\begin{array}{l}1.2743^{\mathrm{a}} \\
(2.9939)\end{array}$ & $\begin{array}{l}0.8121^{\mathrm{b}} \\
(2.0963)\end{array}$ & $\begin{array}{c}0.7988 \\
(1.6843)\end{array}$ \\
\hline Liquidity & - & $\begin{array}{c}-0.0229 \\
(-0.7485)\end{array}$ & $\begin{array}{c}0.0264 \\
(0.9296)\end{array}$ & $\begin{array}{c}0.1519^{a} \\
(4.5178)\end{array}$ & $\begin{array}{c}0.1724^{a} \\
(4.5195)\end{array}$ \\
\hline MTBV & + & $\begin{array}{c}-0.1088 \\
(-1.2583)\end{array}$ & $\begin{array}{l}-0.2720^{c} \\
(-1.7670)\end{array}$ & $\begin{array}{l}-0.7080^{a} \\
(-7.2044)\end{array}$ & $\begin{array}{l}-0.6720^{a} \\
(-6.8115)\end{array}$ \\
\hline Quick Ratio & - & $\begin{array}{c}0.1909 \\
(1.0719)\end{array}$ & $\begin{array}{c}-0.0781 \\
(-0.2592)\end{array}$ & $\begin{array}{l}-2.4988^{\mathrm{a}} \\
(-3.8753)\end{array}$ & $\begin{array}{l}-2.2975^{\mathrm{a}} \\
(-2.9432)\end{array}$ \\
\hline$R$-Squared & & 0.2715 & 0.3944 & 0.7140 & 0.7025 \\
\hline
\end{tabular}

${ }^{a}$ Significant at the $1 \%$ level

${ }^{\mathrm{b}}$ Significant at the $5 \%$ level

${ }^{\mathrm{c}}$ Significant at the $10 \%$ level 